\title{
Faktor Risiko Internal dan Eksternal Preeklampsia di Wilayah Kabupaten Pati Provinsi Jawa Tengah
}

\author{
Kasriatun*, Martha Irene Kartasurya**, Sri Achadi Nugraheni** \\ *Puskesmas Wedarijaksa 2, Pati \\ **Fakultas Kesehatan Masyarakat, Universitas Diponegoro, Semarang \\ Email: kasriyatun@gmail.com
}

\section{ABSTRACT}

Regency of Pati is a coastal area, the main cause of maternal death in the last three years is preeclampsia. In 2016, 35\% of maternal death cases were caused by preeclampsia. The study aims to analyze the risk factors for preeclampsia in Pati. The study is an analytic observational studiy by case control design. Subjects are selected purposively consisting of 40 cases of preeclampsia and 120 cases of nonpreeclampsia. Data collection uses structured interviews using questionnaires. Food intake data is obtained from FFQ (Food Frequency Questionnaire). Data analysis uses chi-square and multiple logistic regression. The results show the risk factors for preeclampsia are internal risk factors: family history of preeclampsia $(O R=6.74 ; 95 \%$ CI: 2.54-17.89, obesity $(O R=2.68 ; 95 \% C I: 1.29-5.60)$, history of hypertension $(O R=7.4$; $95 \%$ CI: 2.9118.82), stress $(O R=2.64 ; 95 \% C I: 1.26$ 5.51), and external risk factors: low antioxidant intake $(O R=3.71 ; 95 \% C I$ : 1.23-11.19), high sodium intake $(O R=$ 2.54; 95\% CI: 1.14-5.67), exposure to cigarette smoke $(O R=2.43 ; 95 \% C I$ : 1.14-5.17). Multivariate analysis shows the family history of preeclampsia $(O R=$ 5.32; 95\% CI: 1.63-17.40), obesity ( OR = 4.01; 95\% CI: 1.60-10.09, history of hypertension $(O R=7.38$; 95\% CI: 2.32-
23.45), stress or anxiety $(O R=3.30 ; 95 \%$ CI: 1,31-8,33), low anti-oxidant intake $(O R=4,22 ; 95 \%$ CI: 1,13-15,74) together are the risk factors for the preeclampsia. Variables that are not the risk factors for preeclampsia are maternal age, parity, and excessive weight gain during pregnancy. The study concludes that the most influential risk factor is history of hypertension before pregnancy. This is in accordance with the Pati Regency region which is a coastal area whose most residents tend to consume excess sodium. It is recommended to include history of hypertension, family history of preeclampsia, obesity, and stress in the antenatal care history for the early detection of preeclampsia.

Keywords: Preeclampsia; Internal Risk Factors; External Risk Factors.

\section{PENDAHULUAN}

Penyebab langsung Angka Kematian Maternal di Indonesia adalah perdarahan $30,3 \%$, preeklampsia $27,1 \%$, infeksi $7,3 \%$, dan penyebab lain 40,8\% . Preeklampsia masih menduduki ranking yang tinggi setelah perdarahan. ${ }^{1}$ Preeklampsia adalah kondisi yang terjadi pada kehamilan yang ditandai dengan adanya hipertensi disertai adanya proteinuria disertai oedema akibat 
kehamilan setelah 20 minggu atau segera setelah persalinan. ${ }^{2,3}$

Preeklampsia merupakan penyebab terbesar kematian ibu di Kabupaten Pati. Pada tahun 2014 kematian maternal karena preeklampsia sebesar $11,7 \%$ dan bukan merupakan penyebab utama AKI di Kabupaten Pati, mengalami kenaikan yang signifikan pada tahun 2015 sebesar 24\%, dan tahun 2016 mencapai 35\%. ${ }^{4}$

Kematian ibu akibat preeklampsia kejadiannya makin meningkat tiap tahun di Kabupaten Pati. Banyak faktor yang sering ditemukan penyebab terjadinya preeklampsia (multiple causation), baik itu faktor internal (usia ibu, Obesitas, paritas, jarak kehamilan, riwayat keturunan, riwayat preeklampsia, stres dan kecemasan, serta riwayat hipertensi) maupun eksternal ibu (paparan asap rokok, status pendidikan, riwayat antenatal care/ ANC serta pengaruh zat gizi yang dikonsumsi ibu)., Namun faktor-faktor risiko preeklampsia seringkali sukar ditentukan mana yang menjadi sebab dan mana yang menjadi akibat. $^{7}$

Banyak faktor yang bisa meningkatkan risiko terjadinya preeklampsia dalam kehamilan (multipel causation). Faktor risiko yang sering ditemukan baik internal (usia ibu, Obesitas, paritas, jarak kehamilan, riwayat keturunan, riwayat preeklampsia, stres dan kecemasan, serta riwayat hipertensi) maupun faktor dari luar atau faktor eksternal ibu (paparan asap rokok, status pendidikan, riwayat antenatal care/ ANC serta pengaruh zat gizi yang dikonsumsi ibu). ${ }^{8,9}$

Pencegahan preeklampsia dapat dilakukan dengan mengidentifikasi faktor risiko dan pemantauan secara ketat terhadap wanita yang berisiko sehingga diharapkan angka preeklampsia bisa direduksi. Penurunan angka kejadian preeklampsia bisa menurunkan angka kematian ibu di suatu daerah termasuk Kabupaten Pati. ${ }^{12}$ Selain itu penelitian preeklampsia belum banyak dilakukan khususnya di Kabupaten Pati yang merupakan daerah pesisir pantai, dengan angka kejadian preeklampsia yang tinggi dari waktu ke waktu, sehingga diharapkan penelitian ini dapat memberikan inovasi cara baru dalam menanggulangi masalah preeklampsia.

\section{METODE PENELITIAN}

Jenis penelitian ini adalah observasional analitik dengan rancangan kasus kontrol. Subyek sejumlah 40 kasus ibu preeklampsia dan 120 kasus ibu tidak preeklampsia dan dipilih secara purposive sampling. Variabel bebas adalah faktor internal (usia ibu, riwayat keluarga preeklampsia, riwayat preeklampsia, obesitas dan penambahan berat badan yang berlebihan), serta faktor eksternal ibu (paparan asap rokok, asupan antioksidan dan asupan natrium), sedangkan variabel terikat adalah kejadian preeklampsia.

Pengumpulan data dengan menggunakan wawancara terstruktur dan data tentang asupan makanan responden dilakukan dengan metode FFQ (Food Frequency Questionnaire). Analisis data dengan menggunakan analisis univariat, bivariat, dan multivariat. Analisis bivariat dilakukan dengan menggunakan chisquare dan analisis multivariat dengan regresi logistik berganda.

\section{HASIL DAN PEMBAHASAN}

Kabupaten Pati merupakan wilayah pesisir pantai yang sebagian besar penduduknya berprofesi sebagai nelayan dan petani garam. Banyak dari mereka sangat mudah mendapatkan garam dan ikan laut termasuk ikan asin. Namun untuk 
mendapatkan buah dan sayur dapat diperoleh di warung atau di pasar.

Subjek penelitian sebesar 160, meliputi 40 kasus dan 120 kontrol. Karakteristik sampel responden dikelompokkan berdasarkan umur, pendidikan, status pekerjaan, paritas, IMT yang digambarkan pada Tabel 1.

Tabel 1. Karakteristik Responden

\begin{tabular}{|c|c|c|c|}
\hline \multirow[t]{2}{*}{ No } & \multirow[t]{2}{*}{ Variabel } & \multicolumn{2}{|c|}{ Frekuensi } \\
\hline & & $\mathrm{N}$ & $\%$ \\
\hline \multirow[t]{4}{*}{1.} & Usia Ibu & & \\
\hline & $<20$ tahun & 21 & 13,1 \\
\hline & 20-35 tahun & 124 & 77,5 \\
\hline & $>35$ tahun & 15 & 9,4 \\
\hline \multirow[t]{5}{*}{2.} & Pendidikan & & \\
\hline & SD & 19 & 11,9 \\
\hline & SMP & 49 & 30,6 \\
\hline & SMA & 81 & 50,6 \\
\hline & PT & 11 & 6,9 \\
\hline \multirow[t]{3}{*}{3.} & $\begin{array}{l}\text { Status } \\
\text { pekerjaan }\end{array}$ & & \\
\hline & Bekerja & 77 & 48,1 \\
\hline & Tidak bekerja & 83 & 51,9 \\
\hline \multirow[t]{4}{*}{4.} & Paritas & & \\
\hline & 1 kali & 54 & 33,8 \\
\hline & 2-3 kali & 90 & 56,3 \\
\hline & $>3$ kali & 16 & 10 \\
\hline \multirow[t]{3}{*}{5.} & IMT & & \\
\hline & $<18,5$ & 29 & 18,1 \\
\hline & $18,5-22,9$ & 56 & 35 \\
\hline
\end{tabular}

$\begin{array}{lcc}23-24,9 & 19 & 11,9 \\ \geq 25 & 56 & 35\end{array}$

Berdasarkan Tabel 1. Menunjukkan bahwa sebagian besar ibu hamil berumur 20-35 tahun. Hal ini menunjukkan bahwa umur responden terbanyak merupakan usia reproduksi yang sehat, yang merupakan usia yang aman untuk melahirkan. Pendidikan terakhir responden menunjukkan bahwa sebagian besar telah menyelesaikan wajib belajar 12 tahun yaitu lulusan SMA, sedangkan jenis pekerjaan ibu mayoritas adalah sebagai ibu rumah tangga. Menurut jumlah paritas sebagian besar responden paritas 2-3 kali. Data hasil pengukuran IMT menunjukkan bahwa responden dengan IMT kategori normal $(18,5-22,9)$ jumlahnya sama dengan responden yang obesitas $(\geq 25)$.

Analisis adalah untuk melihat faktor risiko dan keterkaitan dari variabel bebas terhadap variabel terikat, dimana kedua variabel berskala nominal maka uji yang digunakan adalah uji chi-square.

Hasil penelitian ini berdasarkan kategori faktor risiko internal dan faktor risiko eksternal. Adapun hasil uji analisis bivariat digambarkan dalam Tabel 2 .

Tabel 2. Hasil Analisis Bivariat

\begin{tabular}{|c|c|c|c|c|c|c|c|}
\hline \multirow[b]{2}{*}{ No } & \multirow[b]{2}{*}{ Variabel } & \multicolumn{2}{|c|}{ Kasus } & \multicolumn{2}{|c|}{ Kontrol } & \multirow[b]{2}{*}{ OR $(95 \%$ CI) } & \multirow[b]{2}{*}{$\mathbf{P}$} \\
\hline & & $\mathbf{N}$ & $\%$ & $\mathbf{N}$ & $\%$ & & \\
\hline \multicolumn{8}{|c|}{ Faktor Internal } \\
\hline 1. & Usia ibu & & & & & & \multirow{3}{*}{0,512} \\
\hline & $<20$ th, $>35$ th & 11 & 27,5 & 25 & 20,8 & 1,44 & \\
\hline & $20-35$ tahun & 29 & 72,5 & 95 & 79,2 & $(0,36-3,28)$ & \\
\hline \multirow[t]{3}{*}{2.} & Riwayat preeklampsia keluarga & & & & & \multirow{3}{*}{$\begin{array}{c}6,74 \\
(2,54-17,89)\end{array}$} & \multirow{3}{*}{0,0001} \\
\hline & Ada & 13 & 32,5 & 8 & 6,7 & & \\
\hline & Tidak ada & 27 & 67,5 & 112 & 93,3 & & \\
\hline \multirow[t]{3}{*}{3.} & Obesitas & & & & & & \multirow{3}{*}{0,013} \\
\hline & Obesitas & 21 & 52,5 & 35 & 29,2 & \multirow{2}{*}{$2,68(1,29-5,60)$} & \\
\hline & Tidak obesitas & 19 & 47,5 & 85 & 70,8 & & \\
\hline \multirow[t]{3}{*}{4.} & Penambahan berat badan berlebihan & & & & & \multirow{3}{*}{$1,59(0,55-4,55)$} & \multirow{3}{*}{0,39} \\
\hline & Ya & 6 & 15 & 12 & 10 & & \\
\hline & Tidak & 34 & 85 & 108 & 90 & & \\
\hline 5. & Paritas & & & & & & \\
\hline
\end{tabular}




\begin{tabular}{|c|c|c|c|c|c|c|c|}
\hline & $\begin{array}{l}\text { Primigravida } \\
\text { Multigravida }\end{array}$ & $\begin{array}{l}11 \\
29\end{array}$ & $\begin{array}{l}27,5 \\
72,5\end{array}$ & $\begin{array}{l}43 \\
77\end{array}$ & $\begin{array}{l}35,8 \\
64,2\end{array}$ & $0,68(0,31-1,49)$ & 0,440 \\
\hline 6. & $\begin{array}{l}\text { Riwayat hipertensi } \\
\text { Ada } \\
\text { Tidak ada }\end{array}$ & $\begin{array}{l}15 \\
25\end{array}$ & $\begin{array}{l}37,5 \\
62,5\end{array}$ & $\begin{array}{l}9 \\
111\end{array}$ & $\begin{array}{l}7,5 \\
92,5\end{array}$ & $7,4(2,91-18,82)$ & 0,0000 \\
\hline 7. & $\begin{array}{l}\text { Stres / kecemasan } \\
\text { Stress } \\
\text { Tidak stress }\end{array}$ & 20 & $\begin{array}{l}50 \\
50\end{array}$ & $\begin{array}{l}33 \\
87\end{array}$ & $\begin{array}{l}27,5 \\
72,5\end{array}$ & $2,64(1,26-5,51)$ & 0,015 \\
\hline $\begin{array}{c}\text { Fak } \\
1 .\end{array}$ & $\begin{array}{l}\text { Pr Eksternal } \\
\text { Asupan antioksidan } \\
\text { Kurang } \\
\text { Cukup }\end{array}$ & $\begin{array}{c}36 \\
4\end{array}$ & 10 & $\begin{array}{l}85 \\
35\end{array}$ & $\begin{array}{l}70,87 \\
29,2\end{array}$ & $3,71(1,23-11,19)$ & 0,026 \\
\hline 2. & $\begin{array}{l}\text { Asupan natrium } \\
\text { Lebih } \\
\text { Cukup }\end{array}$ & $\begin{array}{l}14 \\
26\end{array}$ & $\begin{array}{l}35 \\
65\end{array}$ & $\begin{array}{l}21 \\
99\end{array}$ & $\begin{array}{l}17,5 \\
82,5\end{array}$ & $2,54(1,14-5,67)$ & 0,036 \\
\hline 3. & $\begin{array}{l}\text { Paparan asap rokok } \\
\text { Terpapar } \\
\text { Tidak terpapar }\end{array}$ & $\begin{array}{l}17 \\
23\end{array}$ & $\begin{array}{l}42,5 \\
57,5\end{array}$ & $\begin{array}{l}28 \\
92\end{array}$ & $\begin{array}{l}23,3 \\
76,7\end{array}$ & $2,43(1,14-5,17)$ & 0,033 \\
\hline
\end{tabular}

Usia ibu $<20$ tahun, $>35$ tahun bukan merupakan faktor risiko preeklampsia. Hasil penelitian berbeda dengan teori faktor penyebab preeklampsia, karena berdasarkan kelompok usia justru kejadian preeklampsia didominasi pada kelompok usia reproduksi sehat yaitu usia 20-35 tahun. Hal ini disebabkan karena responden yang preeklampsia walaupun diusia 20-35 tahun namun banyak faktor lain yang mempengaruhinya antara lain responden kebanyakan obesitas dan mempunyai riwayat hipertensi sebelum kehamilannya.

\section{Faktor Risiko Internal}

Sebagian besar responden tidak ada riwayat keluarga preeklampsia, namun responden mempunyai riwayat keluarga preeklampsia sebagian besar mengalami preeklampsia sebesar 32,5\% dibandingkan dengan kontrol sebesar 6,7\%. Gambaran riwayat keluarga preeklampsia dalam gambar 1.

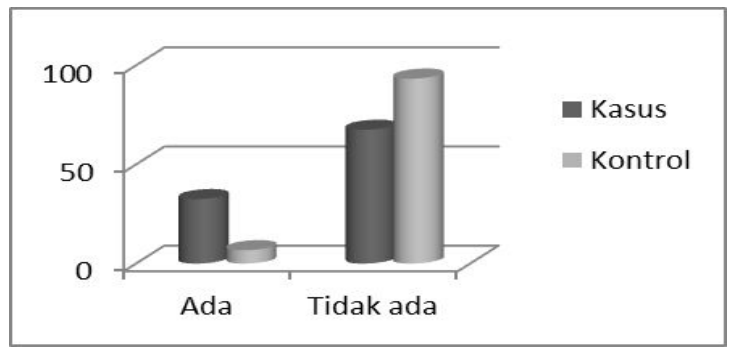

\section{Gambar 1. Riwayat Keluarga Preeklampsia Pada Subjek Kasus dan Kontrol}

Ibu dengan riwayat preklampsia keluarga mempunyai risiko terjadinya preeklampsia yaitu sebesar 6,74 kali lipat. Hal ini sesuai dengan teori yang menyatakan faktor preeklampsia, mempengaruhi terjadinya invasi trofoblast yang tidak normal sehingga bisa menyebabkan terjadinya iskemia placenta yang berperan dalam patogenesis preeklampsia. $^{8}$

Obesitas banyak dijumpai pada ibu yang menderita preeklampsia yaitu sebesar $52,5 \%$ daripada kontrol hanya $29,2 \%$.

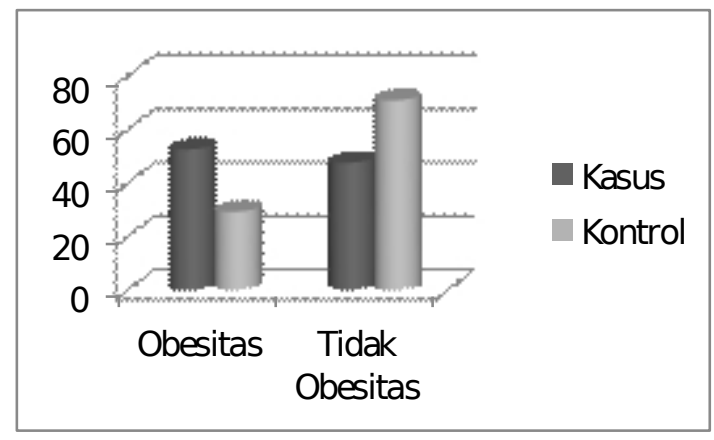

Gambar 2. Obesitas Pada Subjek Kasus dan Kontrol 
Obesitas merupakan faktor risiko preeklampsia. Ibu ibu dengan obesitas mempunyai risiko terjadinya preeklampsia yaitu sebesar 2,68 kali lebih besar dibanding dengan ibu yang tidak obesitas. Hal ini sejalan dengan penelitian yang dilakukan di Manado menyatakan bahwa ibu hamil yang menderita obesitas berisiko 4 kali lebih besar untuk terjadinya preeklampsia dibanding ibu hamil yang tidak menderita obesitas.

Obesitas atau berat badan yang berlebihan disamping menyebabkan kolesterol tinggi dalam darah dan bisa menjadi penyebab terjadinya resistensi insulin. Resistensi insulin ini dapat meningkatkan tekanan darah dalam kehamilan melalui aktivasi sistem saraf simpatis, retensi sodium renal, peningkatan transport kation, dan yang berhubungan dengan disfungsi endotel yang kemudian diikuti dengan kelainan multi organ. Sindroma resistensi insulin ini memiliki peran penting dalam patogenesis preeklampsia. $^{8}$

Penambahan berat badan yang berlebihan selama kehamilan bukan merupakan faktor risiko untuk terjadinya preeklampsia. Penambahan berat badan dikategorikan berdasarkan nilai IMT responden pada K1 (kunjungan pertama pada awal kehamilan). Hasil penelitian ini didukung oleh penelitian yang dilakukan Quedarusman (2012) yang menyatakan bahwa penambahan berat badan yang berlebihan bukan merupakan faktor risiko terjadinya preeklampsia. ${ }^{9}$

Ibu dengan primigravida bukan merupakan faktor risiko preeklampsia. Penelitian ini sesuai dengan penelitian yang dilakukan sebelumnya oleh Gustri (2016) yang menyatakan bahwa tidak ada hubungan yang signifikan antara status paritas ibu dengan kejadian preeklampsia. ${ }^{10}$ Hasil penelitian ini menyatakan bahwa ibu dengan multigravida lebih banyak menderita preeklampsia dari pada ibu dengan paritas primigravida.

Ibu dengan riwayat hipertensi sebelum kehamilan banyak dijumpai pada preeklampsia yaitu sebesar $37,5 \%$, daripada kontrol sebesar 7,5\%.

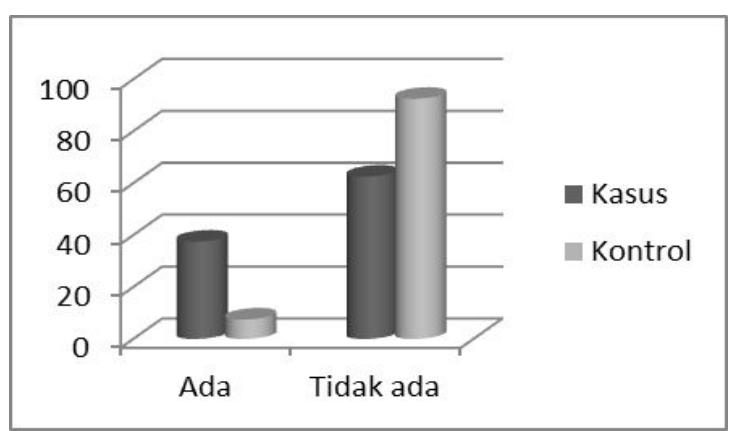

Gambar 3. Riwayat Hipertensi Pada Subjek Kasus dan Kontrol

Riwayat hipertensi merupakan faktor risiko preeklampsia. Ibu kelompok riwayat hipertensi mempunyai risiko terjadinya preeklampsia yaitu sebesar 7,4 kali dibandingkan dengan ibu dengan kelompok yang tidak ada riwayat hipertensi. Hal ini sesuai dengan hasil penelitian sebelumnya yang dilakukan di Yogyakarta yang menyatakan bahwa mempunyai risiko untuk terjadi preeklampsia pada kehamilannya yaitu 7 kali lebih besar dibandingkan dengan wanita yang tidak mempunyai riwayat hipertensi sebelum hamil. ${ }^{11}$

Status kesehatan wanita sebelum dan selama kehamilan adalah faktor penting yang mempengaruhi timbul dan berkembangnya komplikasi. Riwayat hipertensi merupakan salah satu faktor yang dapat dihubungkan dengan kejadian preeklampsia dalam kehamilan. Angka kejadian preeklampsia akan meningkat pada hipertensi kronis, karena pembuluh darah placenta sudah ada gangguan. Hipertensi kronik merupakan faktor 
predisposisi terjadinya preeklampsia. Bila ibu sebelumnya sudah menderita preeklampsia, maka keadaan ini akan memperberat keadaan ibu yang bisa berpotensi menjadi preeklampsia berat. ${ }^{7}$

Hasil penelitian menunjukkan bahwa Ibu dengan stres atau kecemasan cenderung menderita preeklampsia sebesar $50 \%$ daripada kontrol sebesar $27,5 \%$.

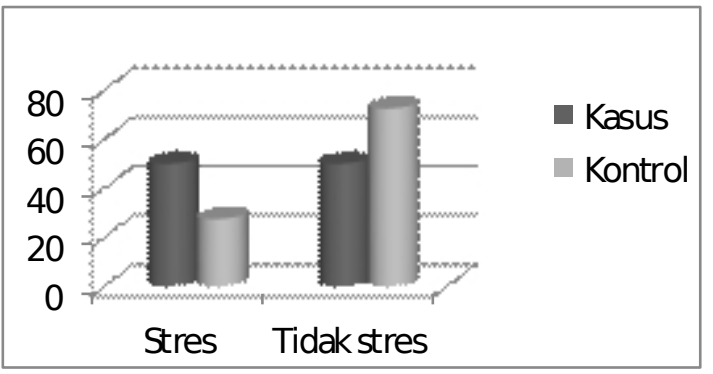

Gambar 4. Stres Pada Subjek Kasus dan Kontrol

Stres merupakan faktor risiko preeklampsia. Ibu yang menderita stres atau kecemasan selama kehamilannya berisiko 2,64 kali menderita preeklampsia dibandingkn ibu yang tidak mengalami stres atau kecemasan.Variabel stress ini diukur berdasarkan kondisi ibu saat awal kehamilan. Penelitian ini sesuai dengan penelitian sebelumnya yang meyatakan bahwa ibu hamil dengan stress atau kecemasan mempunyai risiko untuk terjadinya preeklampsia sebesar 6,5 kali lipat dibanding ibu hamil yang tidak mengalami stress atau kecemasan selama kehamilannya. $^{12}$

Stres merupakan suatu kondisi yang tidak stabil antara jiwa dengan realitas kehidupan. Secara umum kondisi emosi yang dirasakan ibu yang hamil cukup labil. Ibu hamil bisa memiliki reaksi yang ekstrem disertai dengan suasana hatinya kerap berubah dengan cepat. Ibu hamil yang menderita stress atau kecemasan akan terjadi respon flight or fight. Flight adalah suatu reaksi fisiologis tubuh untuk menghindar yang menyebabkan terjadi peningkatan sekresi adrenalin kedalam vaskuler yang dapat menyebabkan adamnya peningkatan denyut jantung dan tekanan darah sistolik, sedangkan Fight adalah suatu reaksi fisiologis tubuh untuk menghadapi ancaman yang bisa menyebabkan sekresi noradrenalin, renin angiotensin sehingga terjadinya peningkatan tekanan darah baik sistolik maupun diastolik. Respon tersebut terjadi karena rangsangan dari sistem saraf simpatis dan sistem endokrin. ${ }^{12}$

\section{Faktor Risiko Eksternal}

Hasil penelitian menunjukkan bahwa sebagian besar ibu hamil masih kurang mengkonsumsi buah, sayur serta suplemen antioksidan. Responden dengan asupan antioksidan yang kurang banyak dijumpai pada kasus preeklampsia dari pada kontrol.

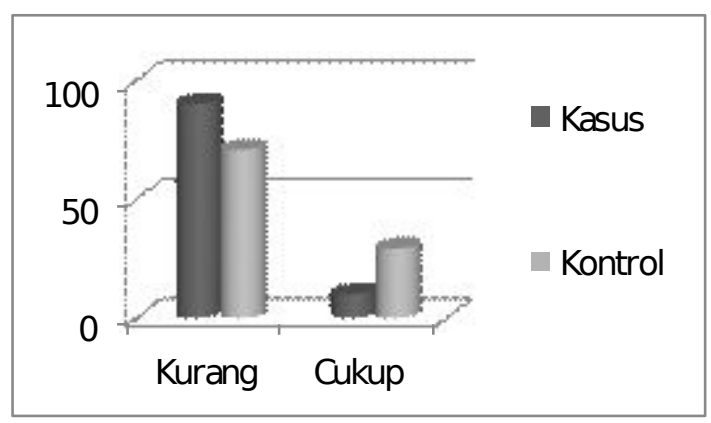

Gambar 5. Asupan Antioksidan Pada Subjek Kasus dan Kontrol

Asupan antioksidan yang rendah merupakan faktor risiko preeklampsia. Ibu dengan asupan antioksidan yang rendah berisiko untuk menderita preeklampsia sebesar 3,71 kali dibandingkan dengan ibu yang dalam kehamilannya cukup dalam mengkonsumsi antioksidan. Hal ini diperkuat dengan penelitian eksperimental randomisasi yang meneliti tentang suplementasi dua macam antioksidan (vitamin $\mathrm{C}$ dan E). Mereka menyimpulkan bahwa kejadian preeklamsia menurun pada kelompok pemakai antioksidan. ${ }^{13}$ 
Hasil penelitian mendukung teori bahwa pemberian antioksidan mampu mengurangi stress oksidatif dan dysfungsi endothel yang bermanifestasi timbulnya peningkatan tekanan darah. ${ }^{14}$ Stress oksidatif merupakan fenomena yang normal terjadi dalam kehamilan, namun pada kehamilan preeklampsia terjadi stress oksidatif yang berlebihan sehingga melebihi ambang batas normal. Pemberian antioksidan yang cukup bisa mencegah terjadinya preeklampsia yang berperan dalam pencegahan terjadinya kerusakan dinding endothel (dysfungsi endothel) dari radikal bebas. ${ }^{15,16}$

Sebagian besar responden tingkat asupan natriumnya dalam kategori cukup, namun responden yang mengkonsumsi natrium yang berlebih lebih banyak dijumpai pada ibu dengan kasus preeklampsia yaitu sebesar $35 \%$ dari pada ibu dengan kehamilan normal sebesar $17,5 \%$.

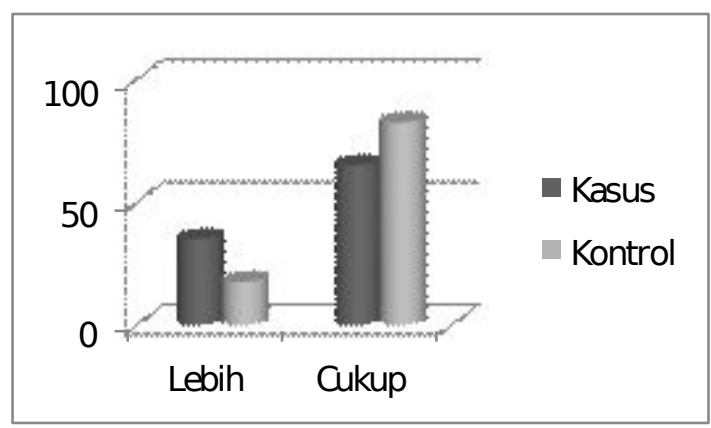

Gambar 6. Asupan Natrium Pada Subjek Kasus dan Kontrol

Asupan natrium yang berlebihan merupakan faktor risiko terjadinya preeklampsia. Ibu dengan asupan natrium yang berlebihan mempunyai risiko untuk terjadinya preeklampsia yaitu sebesar 2,54 kali dibanding dengan ibu yang asupan natriumnya cukup. Hal ini didukung dengan penelitian sebelumnya yang dilakukan di Jerman menyimpulkan adanya hubungan yang signifikan secara statistik antara konsentrasi natrium dalam serum dengan kejadian preeklampsia. ${ }^{17}$

Berdasarkan hasil penelitian yang telah dikemukakan, diharapkan ibu hamil cukup dalam mengkonsumsi natrium sehari-hari yang berarti bahwa ibu hamil tidak boleh kurang dan tidak berlebihan dalam mengkonsumsi natrium sesuai standar yang ditetapkan. Asupan natrium yang berlebih akan menyebabkan terjadinya retensi cairan yang akan meningkatkan volume darah. Konsumsi natrium yang berlebih dapat memperkecil diameter arteri, yang menyebabkan jantung harus memompa lebih keras untuk mendorong volume darah melalui ruang yang makin sempit, yang mnyebabkan tekanan darah akan meningkat. ${ }^{18}$

Sebagian besar responden tidak terpapar asap rokok. Namun ibu yang terpapar asap rokok, banyak dijumpai pada kehamilan preeklampsia sebesar 42,5\%, dari pada kehamilan normal 23,3\%.

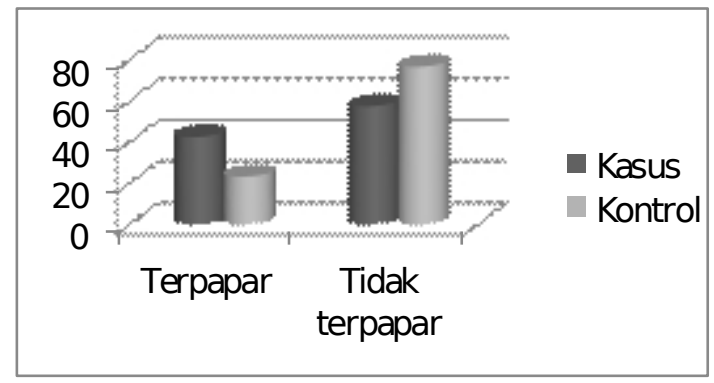

\section{Gambar 7. Paparan Asap Rokok Pada Subjek Kasus dan Kontrol}

Paparan asap rokok merupakan faktor risiko terjadinya preeklampsia. Ibu yang terpapar asap rokok mempunyai risiko untuk terjadinya preeklampsia yaitu sebesar 2,43 kali lipat dibanding dengan ibu yang tidak terpapar asap rokok. Temuan ini sejalan dengan penelitian lain yang menunjukkan bahwa risiko preeklampsia meningkat sebesar 6 kali pada ibu perokok pasif. ${ }^{19}$ 
Asap rokok yang berada di lingkungan perokok mengandung bahan toksik dan karsinogenik yang sama seperti aliran utama yang dihisap oleh perokok aktif. Hal ini menunjukkan bahwa efek perokok pasif hampir sama dengan efek perokok aktif. Pada ibu hamil perokok pasif nikotin dapat meningkatkan denyut jantung dan tekanan darah. Hal ini disebabkan karena perokok pasif akan menghisap $C O$ (carbonmonoksida) yang menyebabakan pasokan $O 2$ jaringan berkurang. Sel tubuh yang kekurangan $O 2$ akan berusaha untuk meningkatkannya melalui kompensasi pembuluh darah dengan jalan spasme yang berakibat meningkatnya tekanan darah. Efek dari paparan asap rokok tersebut akan berpengaruh pada perubahan morfologi plasenta sehingga menyebabkan terganggunya fungsi endothel (dysfungsi endothel). Dysfungsi endothel ini menyebabkan permeabilitas vaskuler meningkat sehingga menyebabkan edema dan proteinuria. ${ }^{20}$

Faktor yang bersama-sama mempengaruhi kejadian preeklampsia adalah riwayat keluarga preeklampsia, obesitas, riwayat hipertensi, stres, serta asupan antioksidan yang rendah. Faktor yang paling berpengaruh secara signifikan terhadap kejadian preeklampsia adalah riwayat hipertensi. Ibu yang memiliki riwayat hipertensi berisiko menderita preeklampsia sebesar 7,38 kali lebih lipat lebih besar dibanding dengan responden yang tidak memiliki riwayat hipertensi. Adapun hasil analisis multivariat digambarkan dalam Tabel 3.

Tabel 3. Hasil Analisis Multivariat

\begin{tabular}{llrrr}
\hline No & Variabel & OR & $\mathbf{9 5 \%} \mathbf{C I}$ & $\begin{array}{c}\boldsymbol{P} \\
\text { Value }\end{array}$ \\
\hline & $\begin{array}{l}\text { Riwayat } \\
\text { preeklampsia } \\
\text { keluarga }\end{array}$ & 5,32 & $1,63-17,40$ & 0,006 \\
2. $\begin{array}{l}\text { Obesitas } \\
\text { 1. }\end{array}$ & 4,01 & $1,60-10,09$ & 0,003
\end{tabular}

\begin{tabular}{llll} 
3. $\begin{array}{llll}\text { Riwayat } \\
\text { hipertensi }\end{array}$ & 7,38 & $2,32-23,45$ & 0,001 \\
4. $\begin{array}{l}\text { Stres } \\
\text { Asupan } \\
\text { antioksidan } \\
\text { yang rendah }\end{array}$ & 4,30 & $1,31-8,33$ & 0,012 \\
& & $1,13-15,74$ & 0,032 \\
\hline
\end{tabular}

\section{KESIMPULAN}

Faktor risiko yang paling kuat adalah riwayat hipertensi ibu sebelum kehamilan. Disarankan agar memasukkan riwayat hipertensi, riwayat keluarga preeklampsia, obesitas, dan stres dalam anamnese pelayanan antenatal untuk mendeteksi dini preeklampsia.

\section{DAFTAR PUSTAKA}

1. Pusdatin Kemenkes RI. Mother's Day. Jakarta; 2013

2. Cunningham, FG, et all . Obstetri Williams. 23rd Edition: MacGraw Hill Professional; 2009

3. Keman, Patomekanisme Preeklampsia Terkini. Malang: UB Press; 2014

4. Dinas Kesehatan Kabupaten Pati. Laporan Tahunan Dinas Kesehatan Kabupaten Pati ; 2014-2016

5. Roberts, M, J., Modnar, M, L., Patrick, E, T., Powers, W, R. 2011. The Role of Obesity in Preeclampsia. Pregnancy Hypertens. 2010 ; 1(1): 6-16

6. Setyawati, B. Et al. Faktor Risiko hypertensi Pada wanita Hamil di Indonesia (Analisa Data Riskesdas 2013). Jakarta; 2013

7. Rozikhan. Faktor-Faktor Risiko Terjadinya Preeklampsia Berat Di Rumah sakit dr H. Soewondo Kendal : Program Magister Epidemiologi Universitas Diponegoro ; 2007

8. Keman, Patomekanisme Preeklampsia Terkini. Malang: UB Press; 2014

9. Quedarusman, H. Hubungan Indeks Masa Tubuh Ibu dan Peningkatan Berat Badab Saat Kehamilan dengan Preeklampsia. Manado : FK Unstrat; 2012.

10. Gustri ,Y., Sitorus, R.J., Utama F.Determinan Kejadian Preeklampsia 
pada Ibu hamil di RSUP Dr. Mohammad Hoesin Palembang. Palembang : Universitas Sriwijaya ; 2016

11. Wardani dan Mawarti. Analisis FaktorFaktor Risiko yang Mempengaruhi Terjadinya Preeklampsia atau eklampsia di RSU PKU Muhamadiyah Yogtakarta Tahun 2007-2009. Yang diakses di

file://D:/TESIS\%20PREEKLAMPSIA /FAKTORFAKTOR\%20PRE\%20EKL AMPSIA.pdf

12. Rengganis, I. Hubungan Antara Kecemasan dengan Preeklampsia. Surakarta : Universitas Sebelas Maret ; 2010

13. Grum, T. Et al. Determinants of Preeclampsia/Eclampsia among Women Attending Delivery Services in Selected Public Hospitals of Addis Ababa, Ethiopia: a case control study. BMC Pregnancy and Childbirth: 2017; Vol 17; no.307.

14. Ardini . Efek Pemberian Kombinasi Vitamin E dan Vitamin C Terhadap Kadar Nitric Oxide (NO) Pada Preeklampsia. Semarang : Fakultas Kedokteran Universitas Diponegoro; 2005

15. Nofrisa M, Hartini dan Hakimi. Kurang Asupan Vitamin A, C, E DAN Beta Karoten Meningkatkan Kejadian Preeklampsia DI RSUP DR. Sardjito, Yogyakarta. Gizi Indon: 2010; vol 33; no,2; 136-142

16. Murray, R. K. Harper Illustrated Biochemistry 26ed. USA: Mc-Graw Hill, 2003

17. Unger, C., at all. Sodium Concentration and Pre-eclampsia: is Salt Restriction of Value?. PMID ; 1998 May-Jun;202(3):97-100

18. Lestari, D. Hubungan Asupan Kalium, Kalsium, Magnesium, Dan Natrium, IMT, Serta Aktifitas Fisik Dengan Kejadian Hipertensi Pada Wanita Usia 30 - 40 Tahun. Semarang: FK UNDIP; 2010

19. Luo Z-C, Wei S-Q, Julien $P$, et all, Plasma cotinine Indicates an
Increased risk of preeclampsia in Previos and Pasive Smokers, Am J Obstet Gynecol; 2014

20. Isnawati,M. Hubungan Ibu Hamil Sebagai Perokok Pasif dengan Kejadian Preeklampsia di RSUD Dr.Moewardi. Surakarta : Universitas Sebelas Maret ; 2012 